\title{
Landslide Hazard Assessment and Zonation by using Slope Susceptibility Evaluation Parameter (SSEP) Rating Scheme- a Case from Debre Sina, Northern Ethiopia
}

\author{
Tamene Tadele
}

Department of Geology, College of Natural and Computational Sciences, Hawassa University, P. O. Box 05

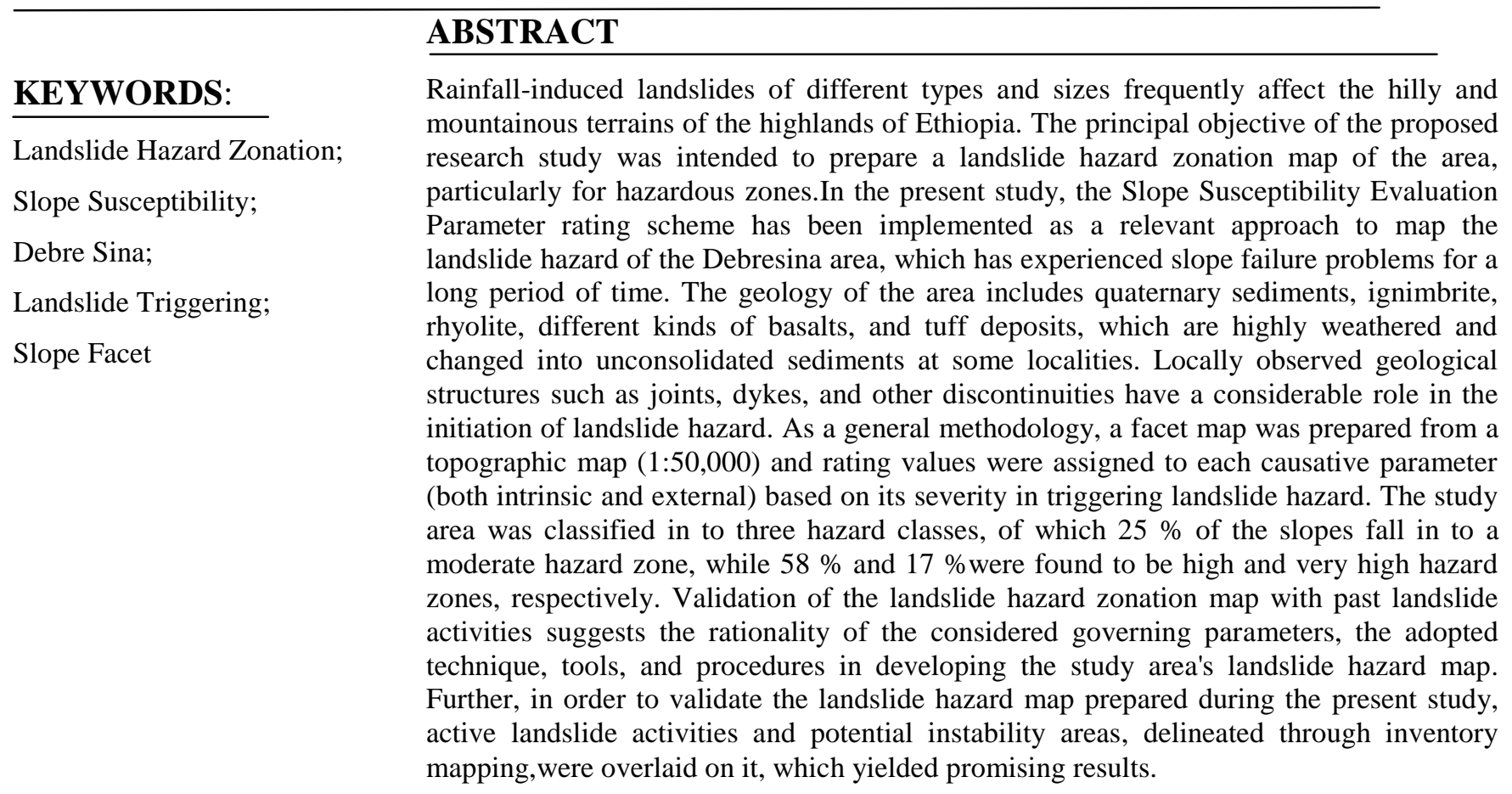

\section{INTRODUCTION}

The earth's surface is always in a dynamic change. These changes are more pronounced in mountainous terrains as a result of different mass wasting processes. One of these masswasting processes is landslides (Hansen, 1984). According to Mohammad et al. (2012), landslide is a slow to rapid downward

*Corresponding author:

Email: tamenetadele@gmail.com, +251916138218 movement of instable rock and debris masses under the action of gravity, whereas Baeza and Corominas (2001), identified landslides occur at a very slow rate, particularly in areas that are very dry and areas that receive sufficient rainfall such that vegetation has stabilized the surface. They may also occur at very high speed, such as in rock slides or landslides, with disastrous consequences, both immediate and delayed, e.g., 
resulting from the formation of landslide dams (Saro and Biswajeet, 2006). Depending on techniques applied, activities involved, data analysis, scale of study, and data availability, various landslide hazard-mapping approaches were introduced. Barredo et al. (2000) divided these methods into inventory, heuristic, statistical, and deterministic approaches. Deterministic slope stability analysis techniques are time consuming and require thorough knowledge on geological and geotechnical considerations with a clear understanding on potential mode of slope failure. Besides, such analysis techniques may be suitably applied to small areas, at the scale of a single slope only (Clerici, 2002; Casagli et al., 2004; Raghuvanshi et al, 2014). McClelland et al. (1997) emphasized the heuristic or expertdriven approach, as a method in which a geomorphological expert decides on the type and degree of hazard for each area, using either a direct mapping or indirect mapping approach. This approach is a time consuming and it depends on a large degree on the expertise of the geomorphologist (Barredo et al, 2000). The statistical approach compares the spatial distribution of existing landslides in relation to different causative factors (Aleotti and Chowdhury, 1999). These methods are good for assessing the spatial probability but there are problems in evaluating either temporal probability or the effects of future environmental changes (Van Westen et al., 2006). The Landslide Hazard Evaluation Factor (LHEF) technique has been utilized successfully over the years by many researchers but as proposed by Raghuvanshi et al. (2014), its major drawback is that it does not account for external causative factors. Further, it does not predict for anticipated adverse conditions during construction and performance stage rather it provides stability condition for the slopes only for the existing conditions prevailed at the slopes during the time of investigation.

In the present study attempt is made to overcome the shortcomings of above approaches and thus, a slope susceptibility evaluation parameter (SSEP) rating technique, which encompasses both intrinsic and external parameters, has been implemented. Landslide problem has been causing lots of casualties, economic and social problems to societies especially to those who are living in the mountainous areas. According to Kifle Woldearegay (2013), the hilly and mountainous terrains of the highlands of Ethiopia are frequently affected by rainfall-induced landslides of different types and sizes. Gebreslassie Mebrahatu (2011) emphasized that the widespread distribution of landslides in Ethiopia is mainly related to the occurrence of several predisposing factors such as; rugged morphology, high topography, and the nature of the outcropping rocks. The triggering factors are essentially connected with the rainfall regime and to a minor extent with seismicity (Gebreslassie Mebrahatu, 2011). According to Asmelash Abay and Barbieri (2012), Debre Sina is located along the southwestern Afar rift margin, and it was frequently affected by landslides in the past few years. It is bounded by different mountains because of which it has experienced rainfall triggered landslides which endangered the life of people and destroyed public and private properties including various infrastructures. 


\section{MATERIALS AND METHODS}

\section{Description of the study area}

\section{Location and climate}

The study area, Debre Sina, is located in Amhara Regional State at a distance of $200 \mathrm{Km}$ toward NNE of Addis Ababa, the capital city of Ethiopia. Geographically, it is bounded between UTM coordinates of 582000-593000 mE; $1080000-1100000 \mathrm{mN}$ (Fig.1). The prevailing climatic condition of the area is "Dega" with mean annual rainfall of $1736 \mathrm{~mm} / \mathrm{year}$ and temperature varying between $10^{\circ} \mathrm{C}$ to $15^{\circ} \mathrm{C}$.

\section{Physiography and the drainage pattern}

Physiographically, the study area is located in the Showan highlands, the smallest highlands of the Ethiopian northwestern highlands, which also includes the Tigrean north central massif, South Western highlands of Gojam and Gondar (Leta Alemayehu, 2007). The Showan plateau is bounded by the Ethiopian rift on the eastern and south eastern sides while Abay gorge border it on the north western side. The study area generally is characterized by highly variable topographical features which are a reflection of the past geological and erosion processes. The landscape includes plateaus, steep hill slopes, deeply incised valleys and gorges. The elevation of the study area ranges from $1500 \mathrm{~m}$ in the Southern sector to $3100 \mathrm{~m}$ in the Northern section.
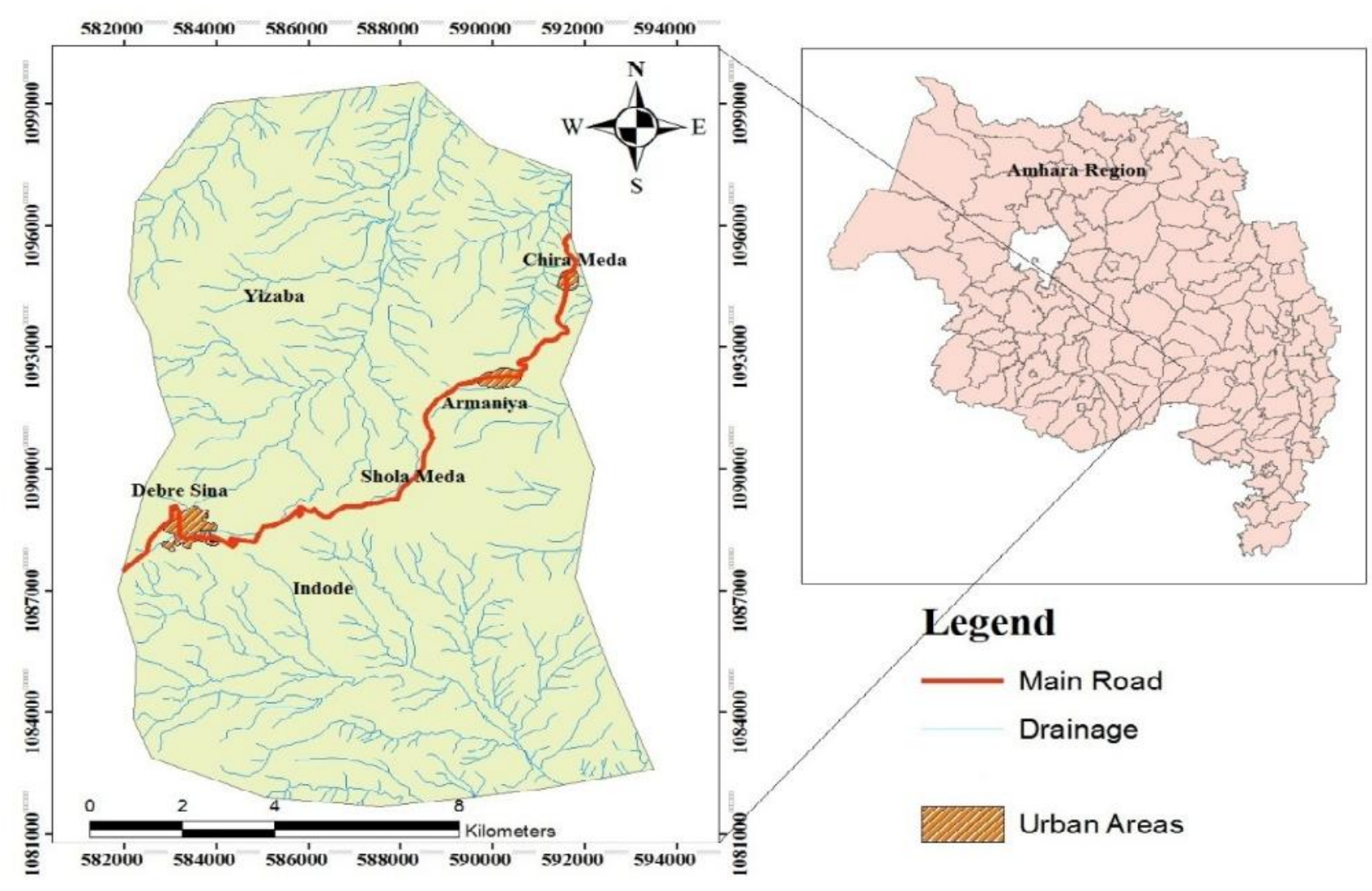

Figure 1. Location map of the study area. 
The drainage system of the area includes many small tributaries feeding the main rivers. Most of the tributaries were dry during the present field visit. Majority of them, especially small tributaries, arise from high mountains and join the main rivers at the valley floor. The general drainage pattern of the study area is dendritic type as portrayed in (fig.1).

\section{Geology}

The Paleozoic-Mesozoic sediments associated with transgression regression of the sea and
Cenozoic volcanic rocks which is directly overlying the Precambrian metamorphic and Mesozoic sedimentary rocks in Ethiopia (Kazmin, 1973). Among these rock units, the geology of the study area and its surroundings can be grouped in to the Cenozoic volcanic rocks (fig.2).According to Astis et al. (1997), the Ethiopian volcanics can be related to two main magmatic stages. The first is the Oligocene - Pliocene large fissure eruptions of basalts which build up thick flood lava sequence known as Ashange and Aiba Basaltic Formations associated with late ignimbrite sheet (AlajiRhyolitic Formations).

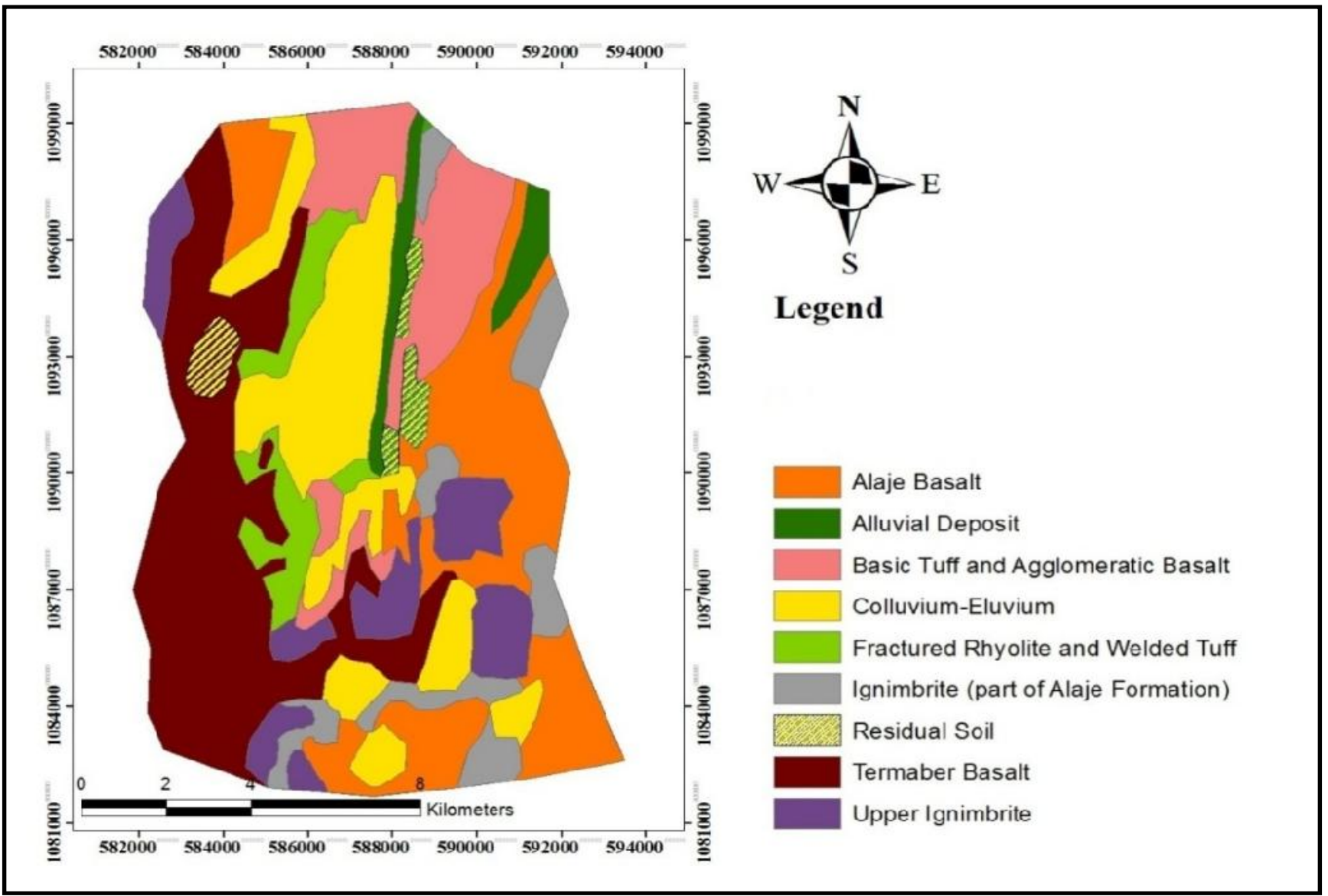

Figure 2. Geological map of the study area. 
This magmatic stage was closed by the formation of huge basaltic shield volcanoes (Tarmaber formation). However in the recent studies about the continental flood basalts of north-western part of Ethiopia, the whole formations were considered as a single unit (Hofmanet al., 1997; Piket al., 1998. Recent classification for continental flood basalt of North western part of Ethiopia was followed as Lower Formation, Upper Formation and the Shield Volcano. Both the Lower and Upper Formation of the continental flood basalt was emplaced 30 my ago within short period of time, less than 1My (Hofmann et al.,1997).

The geologic setting of the central Ethiopian high lands is characterized by the voluminous tertiary volcanicsthat cap the Mesozoic sediments, which are exposed only in the deep incisions by the major rivers. Examples include: Abay Gorge, Jimma Gorge, and Mugher Gorge. According to Mohr and Zenitttin (1988), the Ashangie Formation has been defined by three characteristics: it has experienced a marked dip into the flow sequence of up to $40^{\circ}$; flow thickness averages only about $5 \mathrm{~m}$; and individual flows are rarely traceable for more than a few kilometers along strike. Mohr and Zenitttin (1988), highlighted that the Aiba Formation is typically composed entirely of massive flood basaltic flows, with or without intervening agglomerate beds. According to GezahegnYirgu (1997), two major phases of magmatic activity took place, which produced different formations. A first phase was responsible for the eruption of lavas that built thick succession, up to nearly two kilometers, of fissural basalts (known as Ashange and Aiba Basaltic Formation) and later emplacement of a thick series, up to 500 meters, of silicic lavas mainly in the form of ignimbrite sheets (Alaji Rhyolite Formation). The building up of huge shield-like volcanic complexes followed this fissural magmatic stage from central vents with the predominance of basalts over evolved volcanics (Termaber Basalt Formation).

\section{Methodology}

Most of the landslide hazard zonation methods are based on the basic assumptions that mass movements are caused by the geological, geomorphic, human induced, etc. factors that can be described through physical parameters, and that the knowledge about these conditions enables drawing conclusions on future landslides (Lang et al., 1999). According to Anbalagan (1992), Landslide susceptibility maps can be constructed by using the relation between each landslide and causative factors. Different landslide hazard mapping methodologies in relation to types and scales are portrayed in Table 1. 
Table 1. Methods of landslide susceptibility mapping in relation to types and scales.

\begin{tabular}{|c|c|c|c|c|c|c|c|c|c|}
\hline \multirow[b]{2}{*}{ Types } & \multirow[b]{2}{*}{ Techniques } & \multirow[b]{2}{*}{ Activities } & \multicolumn{4}{|c|}{ Characteristics } & \multicolumn{3}{|c|}{ Scale } \\
\hline & & & 总 & : & : & : & $\begin{array}{l}\stackrel{8}{8} \\
\stackrel{8}{8} \\
\ddot{-}\end{array}$ & 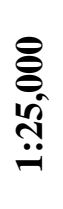 & $\begin{array}{l}\stackrel{8}{8} \\
\stackrel{0}{\Theta} \\
\ddot{-}\end{array}$ \\
\hline \multirow[t]{2}{*}{ Heuristic } & $\begin{array}{l}\text { Geomorphologic } \\
\text { analysis }\end{array}$ & $\begin{array}{l}\text { Use field-expert opinion in } \\
\text { zonation }\end{array}$ & $X$ & $X$ & $X$ & & $X$ & $X$ & $X$ \\
\hline & $\begin{array}{l}\text { Qualitative map } \\
\text { combination }\end{array}$ & $\begin{array}{l}\text { Use expert-based weight values } \\
\text { of parameter maps }\end{array}$ & & $X$ & $X$ & $X$ & $X$ & $X$ & \\
\hline \multirow[t]{3}{*}{ Statistical } & $\begin{array}{l}\text { Bivariate statistical } \\
\text { analysis }\end{array}$ & $\begin{array}{l}\text { Calculate importance of } \\
\text { contributing factor combination }\end{array}$ & & $X$ & & $X$ & & $X$ & \\
\hline & $\begin{array}{l}\text { Multivariate } \\
\text { statistical analysis }\end{array}$ & $\begin{array}{l}\text { Calculate prediction formula } \\
\text { from data matrix }\end{array}$ & & $X$ & & $X$ & & $X$ & \\
\hline & $\begin{array}{l}\text { Probabilistic } \\
\text { analysis }\end{array}$ & $\begin{array}{l}\text { Calculate prediction from } \\
\text { inventory and time period }\end{array}$ & & $X$ & & $X$ & $X$ & $X$ & \\
\hline Deterministic & $\begin{array}{l}\text { Safety } \quad \text { factor } \\
\text { analysis }\end{array}$ & $\begin{array}{l}\text { Apply hydrological and slope } \\
\text { stability models }\end{array}$ & & $X$ & & $\mathrm{X}$ & & & $\mathrm{X}$ \\
\hline Inventory & $\begin{array}{l}\text { Remote sensing and } \\
\text { field investigations }\end{array}$ & $\begin{array}{l}\text { Show locations } \\
\text { characteristics and } \\
\text { landslides }\end{array}$ & $X$ & $X$ & $X$ & & & $X$ & \\
\hline
\end{tabular}

Landslide Hazard Evaluation Factor (LHEF)

\section{Rating Scheme}

The weight rating system is usually designed in many different ways on the basis of studying the impact of each selected factor, for their importance in inducing the instability. Anbalagan (1992), has suggested a landslide hazard evaluation factor (LHEF) rating system that incorporates all the causative factors as listed in Table 2. The LHEF rating scheme may be more relevant as it is based on an empirical approach using important inherent causative factors of slope instability such as; lithology, structure, slope morphometry, land use and land cover, relative relief and hydro-geological conditions. In this scheme, the external factors such as; rainfall and seismicity have not been included. The maximum weight for individual factor has further been sub-divided into a number of categories to form a detailed LHEF rating scheme. This scheme can then be used for calculating total estimated hazard (TEHD) for individual facets. The total estimated hazard (TEHD) value indicates the net probability of instability of a slope facet. It is calculated slope facet-wise, because adjoining slope facets may have entirely different stability conditions. The TEHD value of an individual slope facet is obtained by summing up the ratings of each causative factor, obtained from the LHEF rating scheme for that slope facet. Thus, TEHD value is equal to the sum of ratings of categories of all causative factors. As depicted in Table 2, TEHD values are then arbitrarily categorized into different landslide hazard zones. 
Table 2. Maximum LHEF rating for causative factors for macro-zonation.

\begin{tabular}{ccc}
\hline S.No & Causative Factors & Maximum LHEF Rating \\
\hline $\mathbf{1}$ & Lithology & 2 \\
$\mathbf{2}$ & Relationship of structural discontinuities with slope & 2 \\
$\mathbf{3}$ & Slope morphometry & 2 \\
$\mathbf{4}$ & Relative relief & 1 \\
$\mathbf{5}$ & Land use and land cover & 2 \\
$\mathbf{6}$ & Hydrogeological condition & 1 \\
& Total & 10 \\
\hline
\end{tabular}

LHEF rating scheme, which also follows an empirical approach, takes into consideration individual and net effect of all inherent causative factors responsible for slope instability. Inherent factors are used for preparation of Landslide Hazard Zonation
(LHZ) mapping on macro-zonation approach. Maximum values of rating for individual parameter is awarded keeping in mind its estimated significance in causing slope failure and also to represent overall field conditions (Table 3).

Table 3. LHZ classes on the basis of Total Estimated Hazard (TEHD)

\begin{tabular}{ccc}
\hline S.No & TEHD Value & Hazard Class \\
\hline $\mathbf{1}$ & $<3.5$ & Very Low Hazard (VLH) \\
$\mathbf{2}$ & $3.5-5.0$ & Low Hazard (LH) \\
$\mathbf{3}$ & $5.1-6.0$ & Moderate Hazard (MH) \\
$\mathbf{4}$ & $6.1-7.5$ & High Hazard (HH) \\
$\mathbf{5}$ & $>7.5$ & Very High Hazard (VHH) \\
\hline
\end{tabular}

Slope Stability Susceptibility Evaluation Parameter (SSEP) Rating Scheme

This landslide hazard zonation mapping methodology is a modified technique which is developed by Raghuvanshiet al. (2014) and is applicable in large areas demanding rapid slope stability assessment. It mainly relies on field data and produces landslide hazard zonation map by combining both intrinsic and external slope instability triggering parameters. It was developed in order to overcome the shortcomings of Anbalagan (1992) LHEF rating scheme and is found to be suitable to be applied in present study. The SSEP rating technique involves both intrinsic and external triggering 
parameters responsible for slope instability. The slope stability is mainly governed by intrinsic parameters such as; slope geometry, slope material (lithology or soil type), structural discontinuities, land use and land cover and groundwater (Wang and Niu, 2009). Besides, external parameters, both natural and manmade, which are responsible for triggering instability of slopes, are also considered. The major natural parameters which, triggers the instability in slopes are mainly seismicity (Keefer, 2000) and rainfall (Collison et al., 2000; Dahal et al., 2006). However, there are other natural factors which may trigger slope instability such as; snow/ avalanche, wind, permafrost conditions, shoreline processes and volcanic activities which are not included in SSEP for landslide hazard purpose. Manmade activities mainly include constructions and cultivation practices on slopes (Wang and Niu, 2009). Slope Facet is defined as a land unit, which is characterized by uniform slope geometry in terms of slope inclination and slope direction (Anbalagan, 1992). For this purpose, topographic maps were utilized to demarcate the slope facets. Major or minor hill ridges, primary and secondary streams and other topographical undulations were used to delineate facet boundaries. For the present study, Debre Sina topo map of 1:50,000 was utilized to delineate slope facets of the study area. Rating values was assigned for each intrinsic and external causative factor based on its severity in landslide initiation and the summation of all causative factors will provide Evaluated Landslide Hazard (ELH). Finally landslide hazard zonation (LHZ) map was prepared based on the facet-wise distribution of ELH values. Table 4 portrays distribution of maximum SSEP ratings assigned to each causative factor.

Table 4. Distribution of maximum SSEP ratings assigned to different intrinsic and external factors (Source: Raghuvanshi et al., 2014)

Triggering Parameters

Intrinsic Parameters

1. Slope Geometry

2. Slope Material

3. Structural Discontinuities

4. Land use Land cover

5. Groundwater
Maximum Rating

$\begin{array}{ll}\text { Relative Relief } & 1 \\ \text { Slope Morphometry } & 2\end{array}$

\section{External Parameters}

1. Seismicity

2. Rain Fall 1.5

3. Man-made Activities

1.5

Total 
ELH= Summation of ratings of intrinsic parameters (relative relief + slope morphometry + slope material + structural discontinuity + land use and land cover + groundwater) + Summation of ratings of external parameters (rainfall + seismicity + man-made activities)

\section{RESULTS \& DISCUSSION}

\section{Preparation of facet map}

For convenience and ease assessment of landslide hazard, the study area has been divided into different slope facets which were delineated by major or minor hill ridges, primary and secondary streams, and other topographic undulations. According to Anbalagan (1992), slope facets are characterized by more or less uniform slope inclination and slope direction. These slope facets were prepared from topographic map of scale 1:50,000 and verified in the field. Slope facet was used as base map to award rating values for landslide hazard triggering parameters (Table 5). The slope facets were generally delimited by ridges breaks in slope, streams, spurs, gullies and rivers etc. The facet maps form the basis for the preparation of thematic maps in general and SSEP mapping in particular and individual facet is the smallest mappable unit. In all 60 facets have been delineated in the study area on the basis of visual interpretation of topographic maps fig. 3a.

\section{Landslide Hazard Triggering Parameters}

For landslide hazard zonation, numerical ratings have been assigned to each of the intrinsic and external triggering parameters on the basis of their contribution towards instability of slope, based on standard SSEP rating table.

\section{Intrinsic Parameters}

Intrinsic parameters are considered in hazard mapping because they play a great role in the stability conditions of the slope. These intrinsic parameters are relative relief, slope morphometry, slope material, structural discontinuities, land use and land cover and groundwater (Anbalagan, 1992; Wang and Niu, 2009). Depending upon the given conditions for each of these intrinsic parameters they may have an influence over the stability condition of the slope.

\section{Relative Relief}

Relative relief is one of the important causative factors which may cause slope instability. It affects the instability condition by increasing the gravitational energy which pulls the slope material down the slope. The relative relief map represents the local relief of maximum height between the ridge top and the valley floor within an individual facet (Anbalagan, 1992). Relative relief map of the study area has been prepared by taking the elevation difference between hill top and valley bottom within individual slope facet which was later processed by ArcGIS-10.8 software. In the study area $57 \%$ of the facets fall in very high relative relief whereas $22 \%$ fall in high relief. The remaining facets $(21 \%)$ fall in medium and moderate relative relief (fig.3d). 
This implies that more than half of the study area possesses very high relative relief which renders it susceptible to landslide.

\section{Slope Morphometry}

Slope morphometry map of the study area has been prepared by calculating the slope angles from topographic map. The ratio of height difference between two points in a given facet to horizontal distance gives decimal value of the slope. By taking the inverse tangent of this value slopes in degrees have been manipulated. These slopes fall in to different slope classes as escarpment/cliff $\left(>45^{\circ}\right)$, steep slope $\left(36^{\circ}-45^{\circ}\right)$, moderately steep slope $\left(26^{\circ}-35^{\circ}\right)$, gentle slope $\left(16^{\circ}-25^{\circ}\right)$ and very gentle slope $\left(<15^{\circ}\right)$. Later, slope morphometry map of the study area has been prepared by using ArcGIS-10.8 software. Accordingly, $42 \%$ of the facets experience moderately steep slope $\left(26^{\circ}-35^{\circ}\right)$ while $33 \%$ fall under gentle slopes. The remaining facets possess steep slopes, escarpment and very gentle slope which account for about 10\%, 8\% and $7 \%$, respectively. Generally, most of the facets have moderately steep slope ranging from $26^{\circ}$ to $35^{\circ}$ (fig $3 \mathrm{e}$ ).

\section{Slope Material}

The rock sub classes in SSEP rating system are adopted from classification of rocks based on field estimates of strength by observation which is proposed by (Hoek and Bray, 1997). Thus, slope material is classified as very weak rock (1$5 \mathrm{MPa}$ ), weak rock (5-25 MPa), medium strong rock (25-50 $\mathrm{MPa})$, strong rock (50-100 $\mathrm{MPa})$, very strong rock (100-250 $\mathrm{MPa}$ ) and extremely strong rock (>250 MPa).Slope material map of the study area has been prepared from field observation using 1:50,000 scale topographic map as base map (fig. 3f). Slope material of the study area is characterized by highly weathered and disintegrated rock mass that made it difficult to distinguish some rocks from soil during field visit. Ignimbrite, Alaje Basalt and fractured rhyolite are some of the lithologies on which intense weathering was observed. Generally, $38 \%$ of the study area is covered by medium strength rocks while colluvium materials cover about $27 \%$ of it. Highly weathered materials and weak rocks each comprise $22 \%$ and $13 \%$, respectively.

\section{Land Use Land Cover}

Land use and land cover pattern is one of the important parameters governing slope stability. Vegetation has major role to resist slope movements, particularly for failures with shallow rupture surfaces. A well spreaded network of root system increases the shearing resistance of the slope material due to natural anchoring of slope materials, particularly for soil slopes. Moreover, a thick vegetation or grass cover reduces the action of weathering and erosion, hence adds to stability of the slopes. On the other hand, barren or sparsely vegetated slopes are usually exposed to weathering and erosion action, thus rendering it vulnerable to failure (Wang and Niu, 2009). Slope instability is also induced because of anthropogenic activities, i.e., urbanization, particularly on higher slope angles $\left(>30^{\circ}\right)$. It not only removes vegetation cover but also adds to the natural weight of the slope as surcharge due to the weight of civil structures. In a hill slope with higher slope angle, buildings are usually located by constructing local cut slopes and flat terraces. With this concept urbanization is broadly classified into three categories (Zubair et al., 
2012). A sparsely urbanization slope is where construction terraces are located far apart (more than $15 \mathrm{~m}$ of horizontal spacing) providing a considerable distance between two terraces along the slope. When we see the areal coverage of land covers in the present study area, bushes and shrubs alone cover $29 \%$ of the study area whereas bare land comprises $23 \%$. On the other hand heterogeneous agricultural areas, arable land and forest encompass $20 \%, 17 \%$ and 11 $\%$ of the study area, respectively as shown on fig. 3c. The LULC map of the study area was prepared from ERDAS 9.2 softer and later verified during field visit.

Groundwater conditions of the study area

Groundwater of an area plays vital role in determining the susceptibility of rock/ soil to failure. Hydrological properties of an area include presence of streams, rivers, underground water conditions, saturation state of rock/soil, and drainage pattern of the area. Dislocated water bodies due to presence of discontinuities and shallow water-table conditions in hilly terrains along with heavy rainfall make the slopes prone to instability. According to Murck et al. (1996) during the prolonged monsoon phases, increased pore-water pressure creates favorable conditions for deep-seated landslides. In the present study area, groundwater is not uniformly distributed over all facets. Therefore, groundwater investigation has been conducted facet wise. Some facets have small flowing streams whereas others display wet to dry conditions. As fig. 3b depicts, surface terraces of groundwater of the study area portrays dry slopes $(28 \%)$, wet (22\%), flowing (18\%), damp (18\%) and dripping (14\%), respectively. 


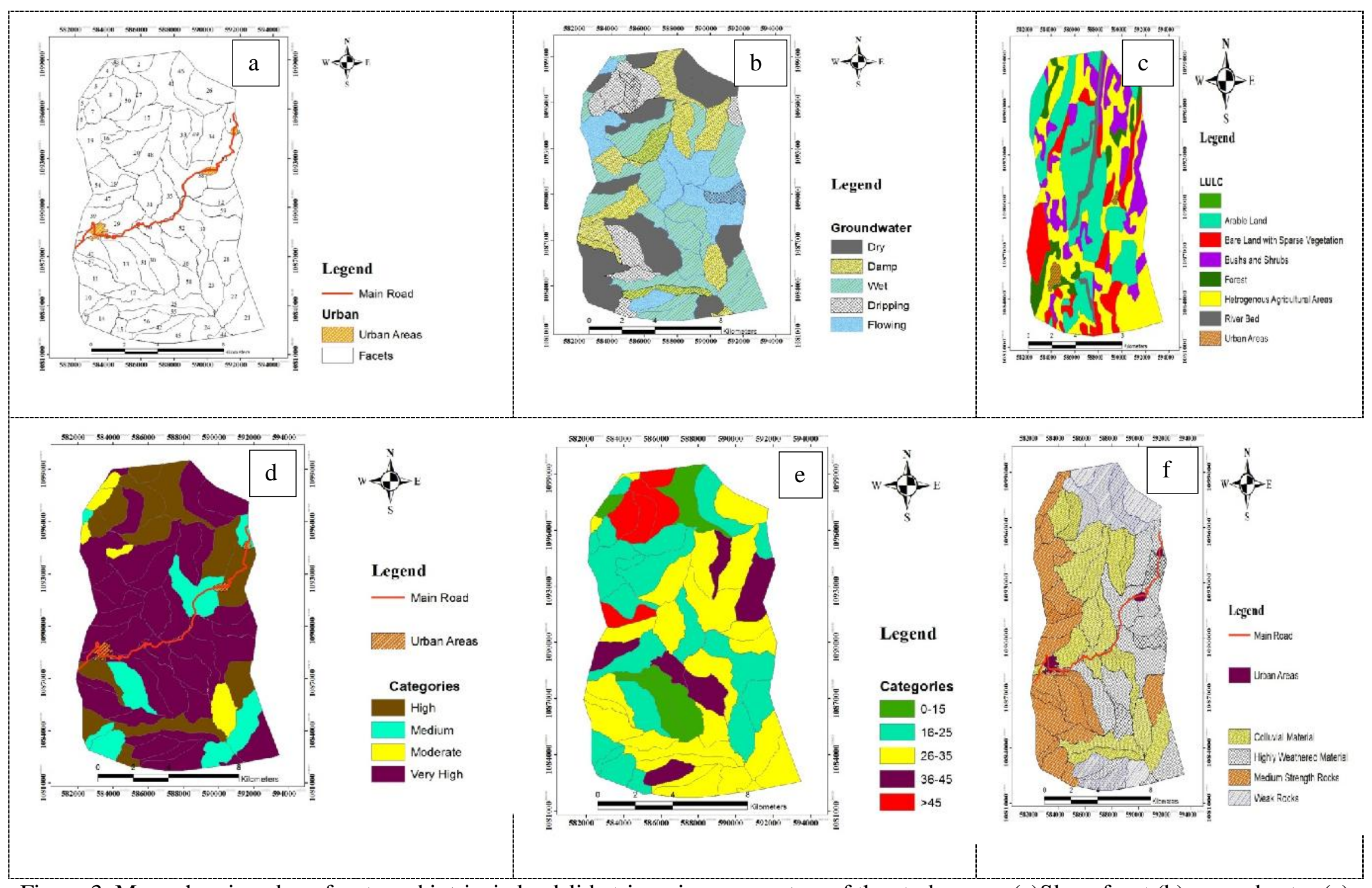

Figure 3. Maps showing slope facets and intrinsic landslide triggering parameters of the study area. (a)Slope facet;(b) groundwater;(c) land use land cover;(d) relative relief;(e) slope morphometry;(f) slope material. 


\section{External Landslide Hazard Triggering Parameters}

\section{Rain Fall}

To assess and see the effect of rainfall to the landslide occurrences of the area, rain fall data for 35 years (1981-2013) was collected from National Meteorology Agency of Ethiopia. It indicates that the maximum, minimum and average annual rainfall in the study area is $3592.7 \mathrm{~mm}, 683.6 \mathrm{~mm}$ and $1,735.591 \mathrm{~mm}$, respectively. The maximum annual rainfall was recorded in the year 1997, while the minimum in the year 2012. The monthly maximum rainfall is always in the months of July and August for all the recorded data. The study area is one of the areas receiving a high rainfall in the country having a bimodal rainfall nature which possesses alternating dry and rainy seasons. It receives exceptionally peak precipitation in the months of July and August. These two months alone contribute $43 \%$ of annual precipitation, which maximizes landslide occurrences. On the other hand months such as; March, April, May and September experience moderate amount of monthly precipitation. Low amount of mean monthly precipitation is recorded in the months of October and November whereas December, January and February are generally regarded as dry months as they receive very low amount of monthly precipitation (fig. 4b)

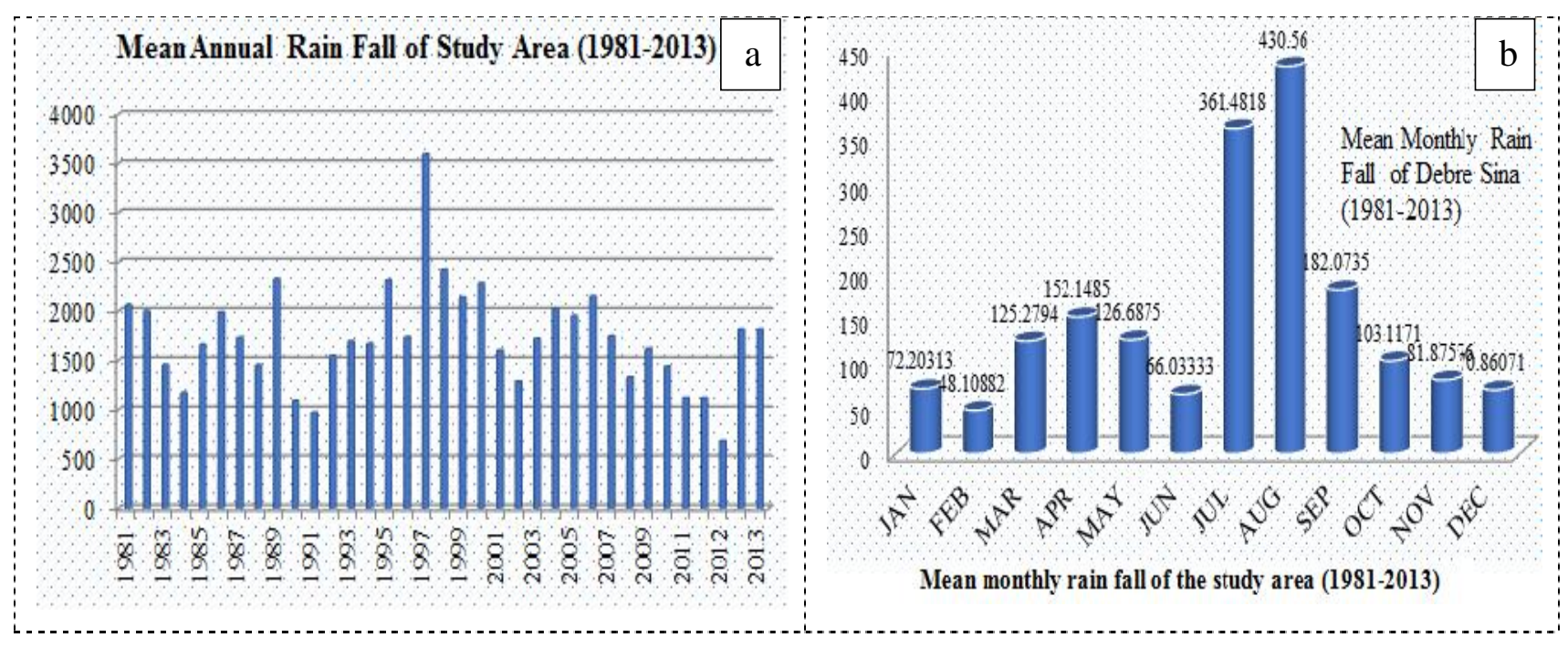

Figure 4. Mean annual and mean monthly rainfall of the study area (1981-2013).

Most of the landslides recorded in the study area occurred when the annual rain fall exceeds the long term average rainfall. However, there were lower occurrences of major landslides between the years of 1983 to 1994 where the amounts of annual rainfalls were lower than the long term average except for 1986 and 1989.
Seismicity

The earthquake shocks may be responsible for triggering new landslides and reactivating old landslides. The vibrations due to earthquake may induce instability, particularly in loose and unconsolidated material on steep slopes. The 
Afar rift margin, where the study area is situated, is known for its earthquake occurrences. Most of the earthquake ranges from small to medium level (Atalay Ayele, 2007). Although not registered, the occurrences of landslide in association with Afar earthquake in the area are common as evidenced by local dwellers. For example, as obtained from local information, there was a landslide occurrence around the Nibamba Gebriel and Sina Aregawi contemporaneous with the 1961 Kara-Kore earthquake.

Figure 5. Seismic risk map of Ethiopia (Source: Laike Mariam Asfaw, 1986).

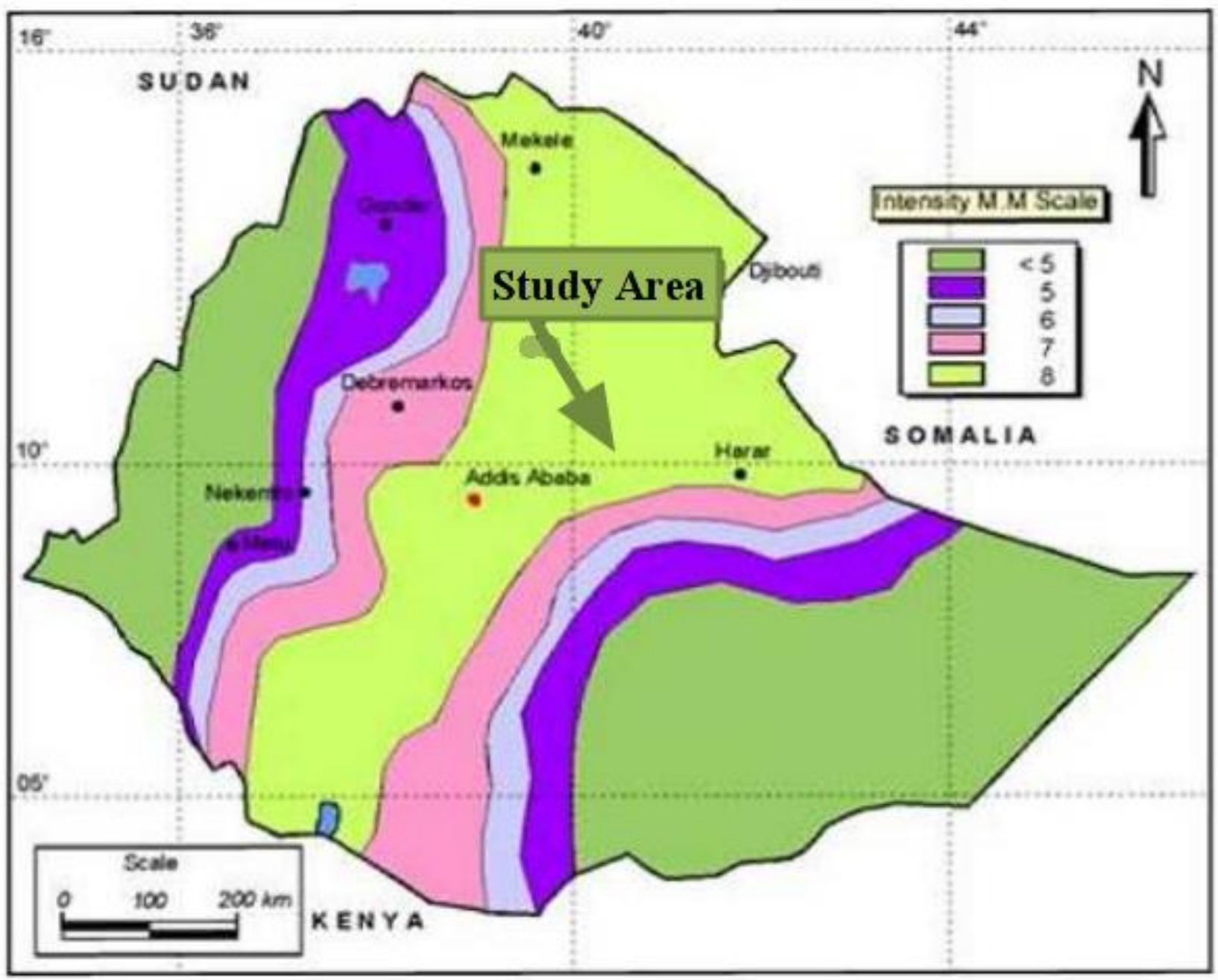

As portrayed above in figure 5, the present study area falls in seismic zone which has an intensity of 8, this zone has a ground acceleration of $0.1-0.5 \mathrm{~g}$. Thus, the rating for ground acceleration of $0.1-0.5 \mathrm{~g}$, as per the standard SSEP table is estimated to be 1.5.Accordingly, this rating value has been distributed to all 60 slope facets in order to generate landslide hazard zonation map of the 
study area. Earthquake induced landslide is so common in most parts of Ethiopia that it needs intensive analysis of causative factors for any landslide including seismic factor.

Table 5.Rating values assigned to each causative parameter in all slope facets

\begin{tabular}{|c|c|c|c|c|c|c|c|c|c|}
\hline$\overbrace{\tilde{c}}^{\infty}$ & 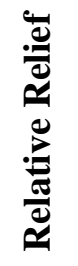 & 旁 & 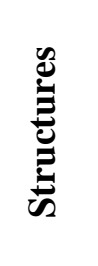 & 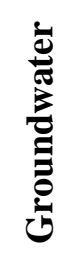 & S & 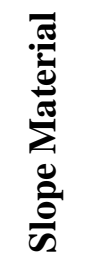 & 总 & 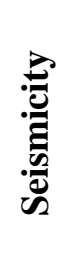 & 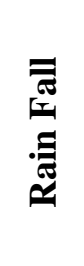 \\
\hline 1 & 0.6 & 0.6 & 1.66 & 0.6 & 0.4 & 0.5 & 1 & 1.5 & 0.75 \\
\hline 2 & 0.8 & 2 & 1.86 & 0 & 0.4 & 0.8 & 1.25 & 1.5 & 0.75 \\
\hline 3 & 0.2 & 0.3 & 2.31 & 0 & 0.75 & 0.8 & 1 & 1.5 & 0.75 \\
\hline 4 & 0.2 & 0.6 & 2.49 & 2 & 0.4 & 0.3 & 1 & 1.5 & 0.75 \\
\hline 5 & 0.6 & 1 & 1.82 & 1 & 1.5 & 0.4 & 0.75 & 1.5 & 0.75 \\
\hline 6 & 0.2 & 0.6 & 2.5 & 1 & 1.5 & 1 & 0.75 & 1.5 & 0.75 \\
\hline 7 & 0.8 & 0.6 & 2.38 & 1.5 & 1.2 & 0.5 & 0.1 & 1.5 & 0.75 \\
\hline 8 & 0.8 & 2 & 1.84 & 1.5 & 1.5 & 0.4 & 0.1 & 1.5 & 0.75 \\
\hline 9 & 0.6 & 0.6 & 1.58 & 0 & 0.4 & 0.4 & 0.1 & 1.5 & 0.75 \\
\hline 10 & 0.8 & 0.6 & 1.88 & 0 & 0.75 & 0.5 & 0.15 & 1.5 & 0.75 \\
\hline 11 & 1 & 1 & 2.49 & 0 & 1.5 & 0.4 & 1.25 & 1.5 & 0.75 \\
\hline 12 & 1 & 1 & 2.23 & 1.5 & 1.5 & 0.1 & 1 & 1.5 & 0.75 \\
\hline 13 & 0.6 & 0.6 & 2 & 1.5 & 0.4 & 0.4 & 1 & 1.5 & 0.75 \\
\hline 14 & 0.6 & 0.6 & 1.86 & 0 & 0.75 & 0.8 & 1 & 1.5 & 0.75 \\
\hline 15 & 0.8 & 1.7 & 2.5 & 1.5 & 1.5 & 1 & 1 & 1.5 & 0.75 \\
\hline 16 & 0.2 & 0.6 & 2.43 & 2 & 1.5 & 1 & 1.25 & 1.5 & 0.75 \\
\hline 17 & 0.8 & 0.6 & 1.86 & 0 & 0.4 & 0.3 & 1 & 1.5 & 0.75 \\
\hline 18 & 1 & 0.6 & 2.24 & 0.6 & 1.2 & 0.3 & 0.5 & 1.5 & 0.75 \\
\hline 19 & 1 & 1.7 & 2.32 & 2 & 1.5 & 1 & 1 & 1.5 & 0.75 \\
\hline 20 & 1 & 0.6 & 1.81 & 0 & 0.4 & 1 & 0.1 & 1.5 & 0.75 \\
\hline 21 & 1 & 1.7 & 2.5 & 2 & 1.5 & 1 & 1.25 & 1.5 & 0.75 \\
\hline 22 & 0.6 & 1 & 1.6 & 1 & 0.4 & 1 & 0.75 & 1.5 & 0.75 \\
\hline 23 & 0.2 & 0.6 & 2.11 & 0.6 & 1.2 & 0.8 & 0.15 & 1.5 & 0.75 \\
\hline 24 & 0.6 & 1 & 2.13 & 0 & 0.4 & 0.8 & 0.1 & 1.5 & 0.75 \\
\hline 25 & 0.8 & 1 & 2.38 & 1 & 0.4 & 0.25 & 0.75 & 1.5 & 0.75 \\
\hline 26 & 1 & 1 & 2.5 & 0 & 0.4 & 0.5 & 0.75 & 1.5 & 0.75 \\
\hline 27 & 0.8 & 2 & 1.71 & 2 & 1.5 & 1 & 1 & 1.5 & 0.75 \\
\hline 28 & 0.8 & 0.6 & 1.94 & 0 & 0.4 & 0.5 & 0.1 & 1.5 & 0.75 \\
\hline 29 & 1 & 0.6 & 2.39 & 0.6 & 0.75 & 1 & 1 & 1.5 & 0.75 \\
\hline 30 & 1 & 0.3 & 1.78 & 0 & 1.5 & 1 & 0.1 & 1.5 & 0.75 \\
\hline
\end{tabular}




\begin{tabular}{|c|c|c|c|c|c|c|c|c|c|}
\hline 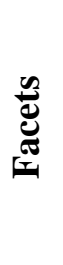 & 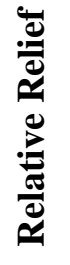 & 总 & 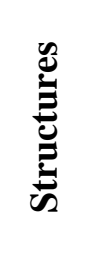 & 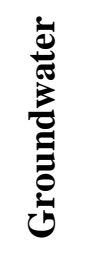 & 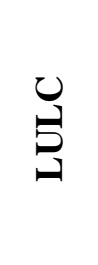 & 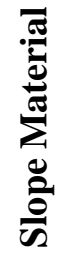 & 苞 & 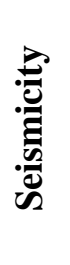 & 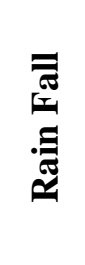 \\
\hline 31 & 1 & 2 & 2.32 & 1 & 1.5 & 1 & 1.25 & 1.5 & 0.75 \\
\hline 32 & 1 & 1 & 2.16 & 2 & 0.4 & 1 & 1.25 & 1.5 & 0.75 \\
\hline 33 & 1 & 1 & 1.6 & 0.6 & 0.75 & 0.5 & 1 & 1.5 & 0.75 \\
\hline 34 & 0.8 & 1 & 2.45 & 0.6 & 1.2 & 0.8 & 0.75 & 1.5 & 0.75 \\
\hline 35 & 1 & 0.6 & 1.62 & 2 & 0.4 & 0.1 & 1.25 & 1.5 & 0.75 \\
\hline 36 & 1 & 1.7 & 2.46 & 2 & 1.5 & 0.4 & 1 & 1.5 & 0.75 \\
\hline 37 & 1 & 0.6 & 2.17 & 2 & 1.5 & 0.8 & 0.75 & 1.5 & 0.75 \\
\hline 38 & 0.6 & 1 & 2.5 & 2 & 1.5 & 1 & 1.25 & 1.5 & 0.75 \\
\hline 39 & 1 & 1.7 & 1.69 & 1 & 0.4 & 0.8 & 0.1 & 1.5 & 0.75 \\
\hline 40 & 0.8 & 1 & 2.22 & 0 & 0.4 & 0.8 & 0.1 & 1.5 & 0.75 \\
\hline 41 & 0.8 & 0.3 & 2.48 & 0.6 & 0.75 & 0.8 & 0.75 & 1.5 & 0.75 \\
\hline 42 & 1 & 1 & 2.03 & 1 & 0.4 & 1 & 0.15 & 1.5 & 0.75 \\
\hline 43 & 1 & 1 & 1.94 & 1 & 1.5 & 0.5 & 1 & 1.5 & 0.75 \\
\hline 44 & 1 & 1.7 & 2.48 & 1.5 & 1.5 & 1 & 1.25 & 1.5 & 0.75 \\
\hline 45 & 1 & 1 & 1.55 & 0.6 & 0.4 & 0.8 & 0.1 & 1.5 & 0.75 \\
\hline 46 & 1 & 0.6 & 1.7 & 0 & 1.2 & 0.5 & 1 & 1.5 & 0.75 \\
\hline 47 & 1 & 1 & 1.64 & 0 & 0.75 & 1 & 0.1 & 1.5 & 0.75 \\
\hline 48 & 1 & 1 & 1.83 & 0.6 & 1.2 & 0.5 & 0.75 & 1.5 & 0.75 \\
\hline 49 & 1 & 1.7 & 2 & 1 & 1.2 & 1 & 0.1 & 1.5 & 0.75 \\
\hline 50 & 1 & 2 & 2.48 & 1.5 & 0.75 & 0.8 & 1.25 & 1.5 & 0.75 \\
\hline 51 & 1 & 0.3 & 2.24 & 0 & 0.75 & 1 & 1 & 1.5 & 0.75 \\
\hline 52 & 1 & 1 & 2.5 & 1 & 1.2 & 1 & 1 & 1.5 & 0.75 \\
\hline 53 & 0.8 & 1.7 & 1.98 & 1 & 1.5 & 0.5 & 0.75 & 1.5 & 0.75 \\
\hline 54 & 1 & 2 & 2.33 & 1 & 1.5 & 0.5 & 0.75 & 1.5 & 0.75 \\
\hline 55 & 1 & 1 & 1.84 & 0.6 & 1.2 & 0.8 & 1 & 1.5 & 0.75 \\
\hline 56 & 1 & 1.7 & 2.4 & 2 & 1.5 & 1 & 1 & 1.5 & 0.75 \\
\hline 57 & 1 & 1 & 2.39 & 0.6 & 1.5 & 0.4 & 1.25 & 1.5 & 0.75 \\
\hline 58 & 1 & 1 & 1.98 & 0 & 1.2 & 0.4 & 0.1 & 1.5 & 0.75 \\
\hline 59 & 1 & 1 & 2.08 & 1.5 & 0.75 & 1 & 1 & 1.5 & 0.75 \\
\hline 60 & 1 & 1.7 & 2.08 & 1 & 1.2 & 0.4 & 1 & 1.5 & 0.75 \\
\hline
\end{tabular}

Estimation of Evaluated Landslide Hazard (ELH)

The evaluated landslide hazard indicates the net probability of instability and has been calculated facet-wise. The ELH of an individual facet was obtained by adding the ratings of the individual causative factors obtained from the SSEP rating scheme. Evaluated Landslide Hazard is estimated as summation of ratings of intrinsic and external parameters. On the basis of evaluated landslide hazard (ELH), three categories of landslide hazard zones have been 
identified for the present study area (fig.6) viz., moderate hazard $(\mathrm{MH})$, high hazard $(\mathrm{HH})$ and very high hazard (VHH). These zones are distributed in accordance with the geology and geomorphology of the area. Areal coverage of moderate hazard is $25 \%$ whereas those of high hazard and very high hazard are $58 \%$ and $17 \%$, respectively. These figures indicate that $75 \%$ of the study area is very susceptible to landslide hazard

\section{Moderate Hazard Zone}

Moderate hazard zone represents relatively safe areas for construction and various infrastructural activities. It covers $25 \%$ of the study area and out of 60 slope facets 15 fall in moderate hazard zone. Moderate hazard zones are mostly distributed in Northern, Central and Southern parts of the study area. Chira Meda area falls in this zone. Even if this zone is not totally suitable, it should not be avoided because it has less probability of landslide occurrence as compared to others.

\section{High Hazard Zone}

The maximum area of the study area is covered by high hazard zone which accounts about $58 \%$ of the study area. This zone represents high susceptibility to landslide hazard as compared to moderate hazard zone. Some of the inventoried landslides are known to occur in this zone. High hazard zone is mostly distributed in Northern, Eastern and Southern parts of the study area. Out of 60 slope facets, 35 are categorized under this zone. Part of the town Debre Sina and Armania also fall in High hazard zone. Those slopes falling in this zone should be partially avoided or detailed study on larger scale
(1:1000) should be done to evaluate the status of stability of these slopes. Suitable control measures should also be identified before taking up constructions in order to minimize related geo-environmental hazards.

\section{Very High Hazard Zone}

This zone represents totally unsuitable areas for constructions and settlement as well as agricultural activities. It covers the least area coverage and accounts $17 \%$ of the study area. Because of very high susceptibility of landslide occurrence in very high hazard zone, it is not advisable and should be totally avoided. About 10 facets of the study area have been identified to be very susceptible to landslide hazard. Among these, very high hazard zones are located in North-Western, Central and SouthEastern part of the study area. Part of town Armania also falls in this zone.

\section{Validation of SSEP Results}

The results obtained in present study correlated with the past landslide events recorded in the study area. Thus, the final Landslide Hazard Zonation map has been checked against the inventoried landslides of the study area for its validity. Landslide inventory map of the study area has been prepared by integrating field observation and GPS data collection with some ideas obtained by interviewing local people living around the study area. Most of the inventory landslides are concentrated in high and very high hazard zones. Out of 36 landslide inventories prepared during the field visit, 22 $(61 \%)$ of them fall in high hazard zone while the remaining 14 (39\%) fall in very high hazard zone. The methodology followed during the present study relates intrinsic and external 
landslide triggering parameters to landslide occurrences. It has produced the results that match to past landslides. Thus, Slope Stability Evaluation Parameter (SSEP) rating scheme is found to be suitable methodology in landslide hazard zonation as it validated with the past landslide hazard events.
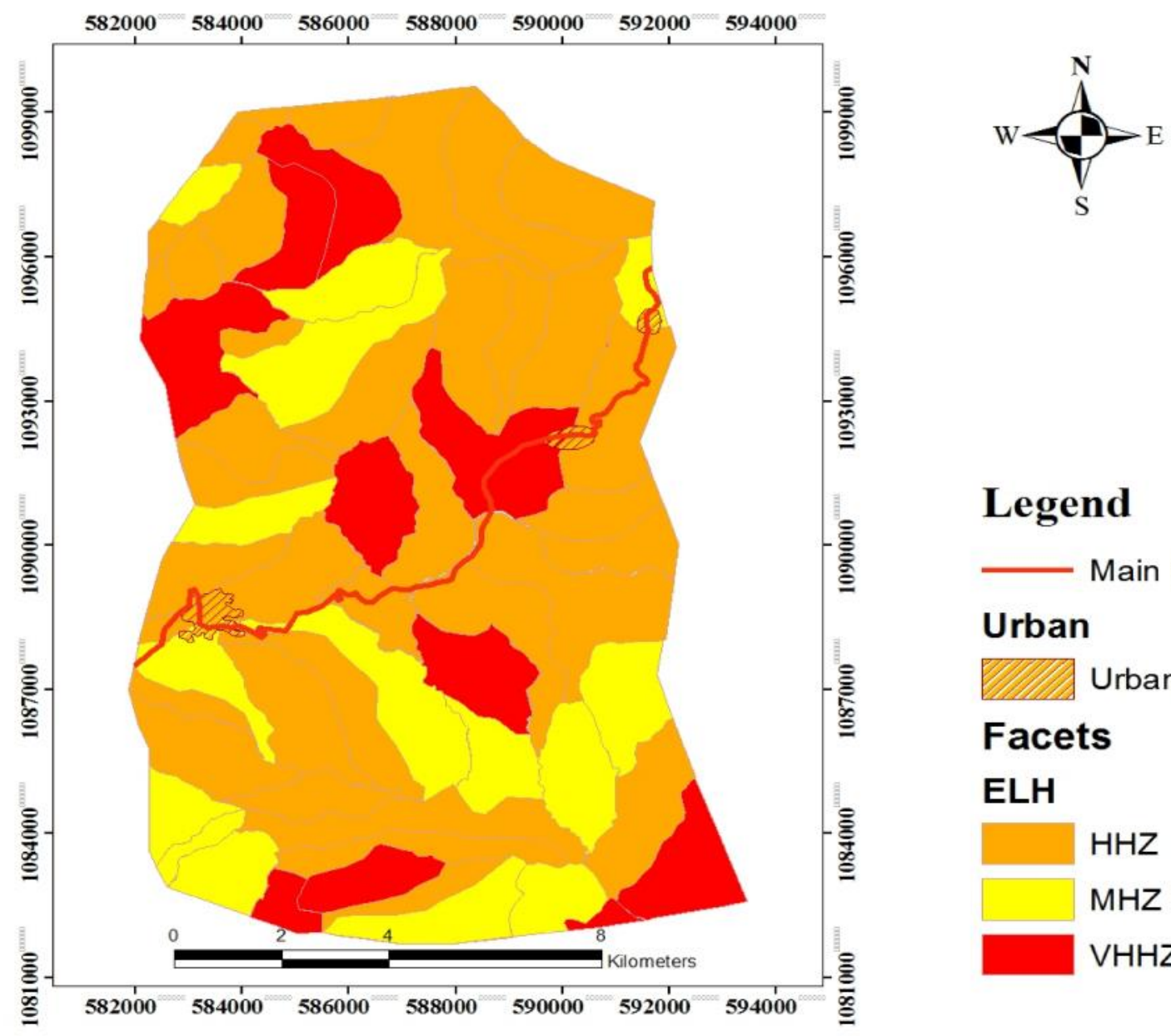

응

을

衷

Legend

Main Road

Urban

Ullas Urban Areas

Facets

ELH

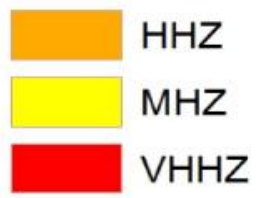

Figure 6. A map showing Evaluated landslide hazard of the study area.

\section{CONCLUSIONS}

The present study area has been affected by landslide hazard which devastated both public as well as private properties including infrastructures. It also threatened the life of people and animals living around the study area. Landslide hazard and fatalities have been reported in the study area for a long period of time. Several landslide hazard assessment approaches are available depending on the kind of data input, study area size, data availability, kind of topography, etc., Each of these approaches has its own advantages and disadvantages. Concerning slope susceptibility in the present study area, areas covered with bare land, shrub and urban classes are more vulnerable to landslides, as compared to 
vegetation cover and forest classes which disfavor landslides. North, Northeast and West facing slopes are favorable to landslides, whereas South, Southwest and West orientation disfavor slope failure. Moreover, slopes inclined at greater than $25^{\circ}$ angle have strong susceptibility to landslides. Distance to streams also has strong relations with landslide occurrence because areas close to streams prove to be highly prone to slope instability suggesting that slope undercutting by stream is an important process. Most of the recent landslides observed during field visit and delineated through inventory mapping fall into high and very high hazard classes suggesting the reliability of the SSEP rating scheme in delineating landslide prone areas of mountainous terrains. This approach is found to be more effective as it heavily depends on realistic field data andhelps to map landslides in large areas in a short period.

\section{Acknowledgements}

The author is grateful to all who have contributed in one or other ways during office and fieldwork. Specifically, I would like to express heart-felt thanks to Tarun Raghuvanshi (Associate Professor of Engineering Geology) for all academic inputs. I also appreciate Addis Ababa University, Department of Geology for providing all facilities including financial coverages needed to accomplish the present study without major obstacles. My appreciation is also extended to Hawassa University, Department of Geology for creating favorable environment during publication process.

\section{References}

Aleotti P. and Chowdhury R. 1999. Landslide Hazard Assessment: Summary, Review and New
Perspectives, Bulletin of Engineering Geology \& Environment. 58:21-44.

Anbalagan R. 1992. Landslide hazard evaluation and zonation mapping in mountainous terrain. Engineering Geology 32:269-277.

Asmelash Abay and Barbieri G. 2012. Landslide Susceptibility and Causative Factors Evaluation of the Landslide Area of Debre Sina, in the Southwestern Afar Escarpment, Ethiopia. Journal of Earth Science and Engineering. 2:133-144

Astis G.D., Volpe L.L., Peccerillo A. and Civetta L. 1997. Volcanological and petrological evolution of Vulcano island (Aeolian Arc, southern Tyrrhenian Sea). Journal of Geophysical Research 102 (B4): 8021-8050.

Atalay Ayele 2007.The volcano-seismic crisis in Afar, Ethiopia, starting September 2005. Earth \& Planetary Sci. letters 255: 177-187

Baeza C. and Corominas J. 2001. Assessment of shallow landslide susceptibility by means of multivariate statistical techniques. Earth Surface Processes and Landforms, 26(12): 1251-1263.

Barredo J.I., Benavides A., Hervas J. and Van Westen C.J. 2000. Comparing heuristic landslide hazard assessment techniques using GIS in the Tirajana basin, Gran Canaria. Island, Spain. International Journal of Applied Earth Observation and Geoinformation 2(1):. 9-23

Casagli N., Catani F., Puglisi C., Delmonaco G., Ermini L. and Margottini C. 2004. An Inventory-Based Approach to Landslide Susceptibility Assessment and its Application to the Virginio River Basin, Italy. Environmental \& Engineering Geoscience 10(3): 203-216.

Clerici A. 2002. A GRASS GIS based Shell script for Landslide Susceptibility zonation by the Conditional Analysis method. In: Proceedings of the Open source GIS - GRASS Users Conference 2002 Trento, Italy, 11-13 September 2002, pp 1-17

Collison A., Wade S., Griffiths J. and Dehn M. 2000. Modelling the impact of predicted climate change on landslide frequency and magnitude in SE England. Eng. Geol. 55: 205-218

Dahal R.K., Hasegawa S., Masuda T. and Yamanaka M. 2006. Roadside slope failures in Nepal during torrential rainfall and their mitigation. Disaster Mitigation of Debris Flows, Slope Failures and Landslides, pp 503-14

Gebreslassie Mebrahatu 2011. Landslide Mapping Assessment using GIS Techniques in Dessie area, Northern Ethiopia. Unpublished MSc Thesis, Vrije Universiteit, Brussles, Belgium, $111 \mathrm{pp}$.

Gezahegn Yirgu .1997. Magma-Crust Interaction during emplacement of Cenozoic Volcanism in Ethiopia: Geochemical evidence from Sheno-Megezez Area, 
Central Ethiopia. Ethiopian Journal of Sciences. 20(1): 49-72

Hansen M.J. 1984. Strategies for classification of landslides. In: Brunsden, D. and Prior D.B. (Eds), Slope Instability. John Willey \& Sons, New York. 1 -25 .

Hoek E. and Bray E.T. 1997. Practical estimates of rock mass strength. International Journal Rock Mechanics Mining Science. 34:1165-1186.

Hofmann C., Courtillot V., Feraud G., Rochette P., Gezahegn Yirgu, Ketefo E. and Pik R. 1997. Timing of the Ethiopian flood basalt event and implications for plume birth and global Change. Nature. 389. 838-841.

Kazmin V. 1973. Geological map of Ethiopia. Ministry of Mines, Energy and Water Resources, Geological Survey of Ethiopia, First edition, Addis Ababa.

Keefer D.V. 2000. Statistical analysis of an earthquakeinduced landslide distribution - the 1989 Loma Prieta, California event. Eng. Geol. 58: 231-249.

Kifle Woldearegay 2013. Review of the occurrences and influencing factors of landslides in the highlands of Ethiopia: With implications for infrastructural development. MEJS. 5(1):3-31.

Laike Mariam Asfaw 1986. Catalogue of Ethiopian Earthquakes, Earthquake parameters, Strain release and Seismic risk, Geophysical Observatory, Faculty of Science, AAU

Lang A., Moya J., Corominas J., Schrott L. and Dikau R. 1999. Classic and new dating methods for assessing the temporal occurrence of mass movements. Geomorphology. 30: 33-52.

Leta Alemayehu 2007. Landslide Susceptibility Modeling Using Logistic Regression and Artificial Neural Networks in GIS: a case study in Northern Showa area, Ethiopia. Unpublished MSc Thesis, 75 pp.

McClelland D.E., Foltz R.B., Wilson W.D., Cundy T.W., Heinemann R., Saurbier J.A. and Schuster R.L. 1997. Assessment of the 1995 \& 1996 floods and landslides on the Clearwater National Forest, Part I: landslide assessment. U.S. Forest Service, $52 \mathrm{pp}$.

Mohammad O., Kumra V.K. and Praveen K. R. 2012. Landslide Susceptibility Mapping in a part of Uttarkashi District (India) by multiple linear regression method. International Journal of Geology, Earth and Environmental Sciences. 2(2): 102-120.

Mohr P. and Zanettin B. 1988. The Ethiopian flood basalt province. Continental flood basalts. In J.D. MacDougall, Kluwer Academic, 63-1110.

Murck B.W., Skinner B.J. and Porter S.C. 1996 Environmental Geology. Wiley, New York, 560 pp.

Pik R., Daniel C., Coulon C., Gezahegn Yirgu, Hofman C. and Dereje Ayalew 1998. The Northwestern Ethiopian flood basalts: Classification and spatial distribution of magma types. Journal of Volcanology and Geothermal Research 81: 91-111.

Raghuvanshi T.K., Jemal Ibrahim and Dereje Ayalew, 2014. Slope stability susceptibility evaluation parameter (SSEP) rating scheme - An approach for landslide hazard zonation. J. Afri. Earth Sci. 99(2): 55-612.

Saro L. and Biswajeet P. 2006. Probabilistic landslide hazards and risk mapping on Penang Island, Malaysia. J. Earth Syst. Sci. 115(6):661-672.

Van Westen C.J., Van Asch T.W.J. and Soeters R. 2006. Landslide hazard and risk zonation - why is it still so difficult?. Bulletin of Eng. Geology and the Envir. 65:167-184.

Wang X. and Niu R. 2009. Spatial Forecast of Landslides in Three Gorges Based On Spatial Data Mining. 9:2035-2061.

Zubair A.M., Panwar M.S. and Parmar M.K. 2012. Landslide Hazard Zonation of District Rudraprayag of Garhwal Himalaya. International Journal of Current Research 4:237-244. 